\title{
EVALUATION OF FORMAL RISK ASSESSMENT IMPLEMENTATION OF MIDDLE EAST RESPIRATORY SYNDROME CORONAVIRUS IN 2018
}

\author{
Evaluasi Pelaksanaan Formal Risk Assessment Middle East Respiratory Syndrome Coronavirus Tahun \\ 2018
}

\section{Della Safera Pradanti}

Public Health Faculty, Universitas Airlangga, della.safera.pradanti-2015@fkm.unair.ac.id

Corresponding Author: Della Safira Pradanti, della.safera.pradanti-2015@fkm.unair.ac.id, Departement of Epidemiology, Public Health Faculty, Universitas Airlangga, Dr. Ir. H. Soetomo Street, Mulyorejo, Surabaya City, East Java, Indonesia, Postal Code 60115

\author{
ARTICLE INFO \\ Article History: \\ Received May, 22th, 2019 \\ Revised form July, 3 ${ }^{\text {rd }}, 2019$ \\ Accepted September, $26^{\text {th }}, 2019$ \\ Published online September, $30^{\text {th }}$, \\ 2019
}

\author{
Keywords: \\ evaluation; \\ middle east respiratory syndrome \\ coronavirus; \\ formal risk assessment; \\ emerging infectious disease
}

\section{Kata Kunci:}

evaluasi;

middle east respiratory syndrome

coronavirus;

penilaian risiko;

penyakit infeksi emerging

\begin{abstract}
Background: Confirmed cases of Middle East respiratory syndrome caused by coronavirus (MERS-CoV) were not found until the end of February 2019 in Indonesia. The spreading threat of MERS-CoV disease in Indonesia is still quite vast, mainly because of the amount of international travel from Indonesia to Saudi Arabia for the purpose of Hajj and Umrah, vacationing, working, or settling in the Arabian Peninsula. Purpose: The aim of this study is to evaluate the implementation of formal risk assessment (FRA) and MERS-CoV risk in Indonesia in 2018, having regard to threat, vulnerability, and capacity. Method: This study is a non-reactive observation study presented descriptively using the literature method and in-depth interviews with staff of the subdirectorat of Penyakit Infeksi Emerging Kementerian Kesehatan Republik. Decision-making for the threat category and vulnerability category is based on the highest threat index and vulnerability values, while the capacity category is based on the lowest capacity index value. Results: This study shows that there are three threat subcategories and two vulnerability subcategories that have high index scores and eight capacity subcategories that have low scores. Conclusion: The implementation of risk assessment for MERS-CoV with the FRA method as a whole has been maximally pursued. However, there are still shortcomings in the results of the research that need to be improved through further interventions to reduce the subcategory values that are high in the threat and vulnerability index and to increase the value of the low capacity index.
\end{abstract}

C2019 Jurnal Berkala Epidemiologi. Published by Universitas Airlangga. This is an open access article under CC-BY-SA license (https://creativecommons.org/licenses/by-sa/4.0/)

ABSTRAK
Latar Belakang: Kasus Middle East Respiratory Syndrome
Coronavirus (MERS-CoV) konfirmasi masih belum ditemukan hingga
akhir Februari tahun 2019 di Indonesia. Ancaman penyebaran
penyakit MERS-CoV di Indonesia masih cukup besar terutama
karena banyaknya riwayat perjalanan internasional menuju Arab
Saudi untuk tujuan ibadah haji dan umrah, berlibur, bekerja maupun

Latar Belakang: Kasus Middle East Respiratory Syndrome
Coronavirus (MERS-CoV) konfirmasi masih belum ditemukan hingga
akhir Februari tahun 2019 di Indonesia. Ancaman penyebaran
penyakit MERS-CoV di Indonesia masih cukup besar terutama
karena banyaknya riwayat perjalanan internasional menuju Arab
Saudi untuk tujuan ibadah haji dan umrah, berlibur, bekerja maupun 


\begin{abstract}
menetap di daerah jazirah Arab. Tujuan: Penelitian ini bertujuan untuk mengevaluasi pelaksanaan Formal Risk Assessment (FRA) dan risiko MERS-CoV di Indonesia tahun 2018 dengan memperhatikan faktor ancaman, faktor kerentanan, dan faktor kapasitas. Metode: Penelitian ini merupakan penelitian observasi non reaktif yang disajikan secara deskriptif dengan metode study literature dan wawancara mendalam dengan staf subdirektorat Penyakit Infeksi Emerging Kementerian Kesehatan Republik Indonesia. Pengambilan keputusan untuk kategori ancaman dan kategori kerentanan diambil berdasarkan nilai indeks ancaman dan kerentanan yang tertinggi, sedangkan untuk kategori kapasitas diambil berdasarkan nilai indeks kapasitas yang terendah. Hasil: Penelitian ini menunjukkan bahwa terdapat tiga subkategori ancaman dan dua subkategori kerentanan yang mendapat nilai indeks yang tinggi serta delapan subkategori kapasitas yang mendapat nilai yang rendah. Kesimpulan: Pelaksanaan penilaian risiko terhadap MERS-CoV dengan metode FRA secara keseluruhan telah diupayakan secara maksimal namun masih terdapat kekurangan dalam hasil penelitian yang perlu diperbaiki melalui intervensi lanjutan untuk menurunkan nilai subkategori yang tinggi pada indeks ancaman dan kerentanan serta meningkatkan nilai indeks kapasitas yang masih rendah.
\end{abstract}

(C2019 Jurnal Berkala Epidemiologi. Penerbit Universitas Airlangga. Jurnal ini dapat diakses secara terbuka dan memiliki lisensi CC-BY-SA (https://creativecommons.org/licenses/by-sa/4.0/)

\section{INTRODUCTION}

In the globalisation era, the level of human and goods mobility is very high and fast. This condition can be a threat when viewed in terms of transmission of diseases from one place to another. The more transmission of disease, the more health problems there are. One health problem that is currently a global concern is emerging infectious diseases. An emerging infectious disease is a disease that had been considered no longer a threat to health, but reappears sporadically in a region, country, and sometimes globally from time to time (Mukherjee, 2017).

Emerging infectious diseases can be a threat to global health security because they can cause outbreak (KLB) that not only cause death but also considerable economic loss; for example, the outbreak of Middle East respiratory syndrome caused by coronavirus (Mers-CoV), which took place in South Korea in 2015, caused the death of $22 \%$ of the population in just two months (MayJune 2015) (Ki, 2015).

MERS-CoV initially appeared in 2012 in Saudi Arabia, then spread to Europe and to Asia. From April 2012 to the end of February 2019, 2,374 confirmed cases of MERS-CoV emerged, with 823 cases resulting in death (WHO, 2019). Confirmed cases of Mers-CoV were undiscovered in Indonesia until the end of February 2019. The spreading threat of MERS-CoV disease in Indonesia is quite vast because of the frequent international travel from Indonesia to Saudi Arabia for the purpose of Hajj and Umrah, vacationing, working, or settling in the Arabian Peninsula. Based on data from Kementerian Agama Republik Indonesia in 2018, the average number of Hajj pilgrims from Indonesia is 200,000 per year and 750,000 per year for Umrah pilgrims (Ministry of Religion RI, 2018).

Treatment of emerging infectious diseases such as MERS-CoV involves strict vigilance of sufferers and suspected sufferers, including those with close contact with sufferers. Preventing the spread of Mers-CoV disease is important because the severity and nature of the disease is still not known. As this disease has the potential to spread rapidly, it constitutes a public health emergency on a worldwide scale. Based on previous research, frequent international travel and annual mass gatherings such as the Hajj and Umrah have enabled MERS-CoV disease to become increasingly widespread (Gardner, Chughtai, \& Maclntyre, 2016).

In 2017, the subdirectorat Penyakit Infeksi Emerging (PIE) Kementerian Kesehatan Republik Indonesia began to implement early detection efforts through the implementation of risk 
assessments in an effort to prevent and control emerging infectious diseases. The implementation of these risk assessment efforts in 2017 was piloted in three provinces in Indonesia, namely Bali, Lampung, and Palembang (Imari \& Lestari, 2017).

The risk assessment developed by PIE is known as a formal risk assessment (FRA). The implementation of FRA generally aims to carry out risk assessments of emerging infectious diseases such as MERS-CoV. FRA is quantitative, which is what distinguishes it from other risk assessment tools. The FRA implementation is expected to provide recommendations or solutions that can be used to prevent MERS-CoV disease (Imari \& Lestari, 2017).

The purpose of this research is to evaluate the implementation of FRA and MERS-CoV risk in Indonesia in 2018 by taking into account threats, vulnerabilities, and capacities.

\section{METHODS}

The type of research used is non-reactive observation of a population in Indonesia presented descriptively using the literature review method and in-depth interviews with staff of PIE; the time unit of observation is 2018.

Primary and secondary data are used. Primary data are obtained through interviews with PIE subdistrict staff to find out the capacity factors that have been carried out in an effort to prevent and control MERS-CoV disease. Secondary data are obtained through documentation studies of weekly reports on emerging infectious diseases, Indonesia's health profile in 2018, and Hajj Infographic of Kementerian Agama Republik Indonesia to answer several questions in the FRA questionnaire.

The first step in implementing FRA tools in MERS-CoV disease is to collect the data needed for the FRA questionnaire. The data contained in the FRA questionnaire in this study is the result of a literature review and in-depth interviews with PIE subdistrict staff. The next step is to fill in the data on the FRA questionnaire sheet using Microsoft Excel, which in the next sheet will produce a weight calculation and index analysis for each category of threats, vulnerabilities, and capacities.

Threats in the context of FRA assessment are characteristic of emerging infectious diseases that have a contagious effect and spread throughout the population where the disease is located. The threat index for MERS-CoV disease is assessed based on the seven assessment subcategories contained in the FRA MERS-CoV questionnaire. The seven subcategories are disease characteristics, treatment, prevention, import risk, attack rate, local transmission risk, and economic impact. The threat index is said to be low if the index calculation from each threat subcategory shows a lower number than the other threat subcategories.

Vulnerability is a condition that provides a great opportunity for the threat of MERS-CoV and the impact on a population. The vulnerability index for MERS-CoV disease is assessed based on four sub-categories of evaluation - namely, the population that travels to infected areas, transportation between provinces and between cities/districts, population density, and the proportion of the population aged $>60$ years. Vulnerability to MERS-CoV disease is said to be high if the index value for each vulnerability subcategory gets a high score.

Capacity is the ability of the government and the community to carry out awareness, prevention, and control of MERS-CoV diseases, namely by minimising threats and vulnerabilities and their impact on the population. Assessment index capacity to condition Mers-CoV is rated by 12 subcategories - namely, public policy, institutional, hospital referrals, laboratory capacity, hospital surveillance, surveillance by health centres, surveillance entrance by Kantor Kesehatan Pelabuhan (KKP), health promotion, competent MERS-CoV epidemiological investigations, rapid motion teams, intervention plans, and countermeasures. Capacity is said to be not right if the capacity index value for each rating subcategory has a low value. This is because the low capacity indicates that the effort or ability of governments and society to raise awareness of, and prevent and control, MERS-CoV is still not optimal.

The results of index calculations are used to draw conclusions for each category. Conclusions are intended as a basis for planning interventions in the prevention and control of MERS-CoV disease. Decision-making for the threat and vulnerability category is based on the highest threat index and vulnerability values, while the capacity category is based on the lowest capacity index value.

\section{RESULTS}

\section{Threat index}

Figure 1 shows the threat index of MERS$\mathrm{CoV}$ disease in 2018 had mixed results. There 
were subcategories that got a low threat index score, but there were also subcategories that still got high index scores. The results of the seven subcategories of MERS-CoV disease threat assessment showed that four of seven subcategories had low threat index values namely, treatment, attack rate, local transmission risk, and economic impact. There were three subcategories with a high threat index value, so intervention efforts are needed to lower the threat index value in these three subcategories. The three subcategories were disease characteristics, prevention, and import risk (Figure 1).

\section{Vulnerability index}

The results of calculations on the vulnerability index indicated a large yield gap. This can be seen from a subcategory that had a very high index value and also a subcategory that had a very low index value. The subcategory that had a very high vulnerability index value was transportation between provinces and between districts/cities, while the subcategory that had a very low vulnerability index value was population travel to infected areas. In general, the priority of the four subcategories for the vulnerability index that need to be prioritised is the implementation of interventions so that vulnerability to MERS-CoV disease can decrease. Some of the interventions that need to be made are interventions on the transportation between provinces and between districts/cities subcategory as well as the proportion of the population aged > 60 years (Figure 2).

\section{Capacity index}

The results showed that out of the 12 subcategories of assessment, four subcategories had high capacity index values - namely, surveillance entrance by the KKP, competent MERS-CoV epidemiological investigations, rapid motion teams, and intervention plans. There were eight subcategories with low capacity index values, namely public policy, institutional, hospital referrals, laboratory capacity, hospital surveillance, surveillance by health centres, health promotion, and prevention budgets (Figure 3).

\section{DISCUSSION}

The advancement of public transportation technology allows people and goods movement between regions and countries to happen in a short time. This certainly has an impact on the threat of disease transmission between regions and countries (Monge-Maillo \& López-Vélez, 2017). It is proven that more than 200,000 people each year take advantage of easier transportation in the form of planes to make pilgrimages to Hajj and Umrah in Saudi Arabia (Ministry of Religion RI, 2018). This is significant because Saudi Arabia has the highest incidence of MERS-CoV cases in the world. Haji and Umrah pilgrims are therefore at risk of MERS-CoV disease. This condition makes state preparedness and mitigation efforts an important thing to do so that the risks of morbidity, mortality, and economic loss can be prevented and anticipated properly (WHO, 2019).

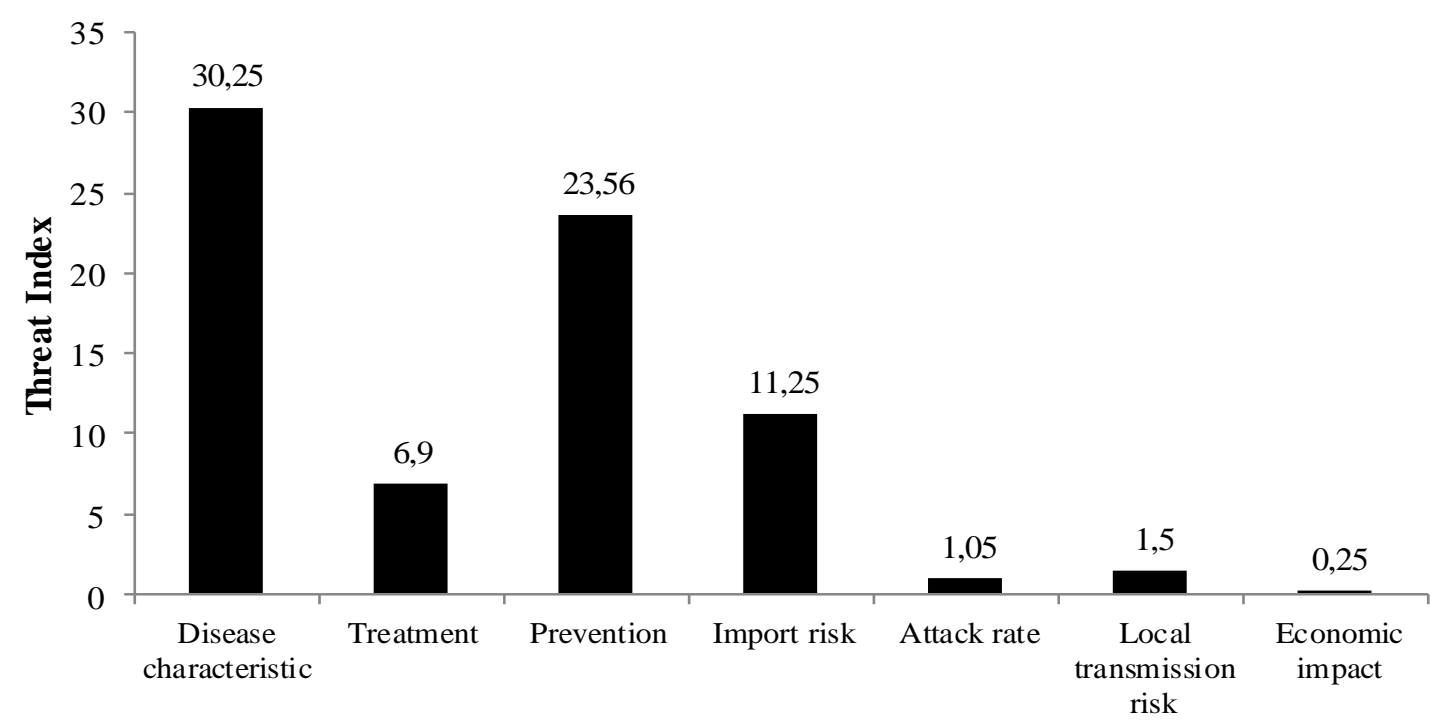

Threat Subcategory

Figure 1. Threat Index Results from Formal Risk Assessment MERS-CoV 


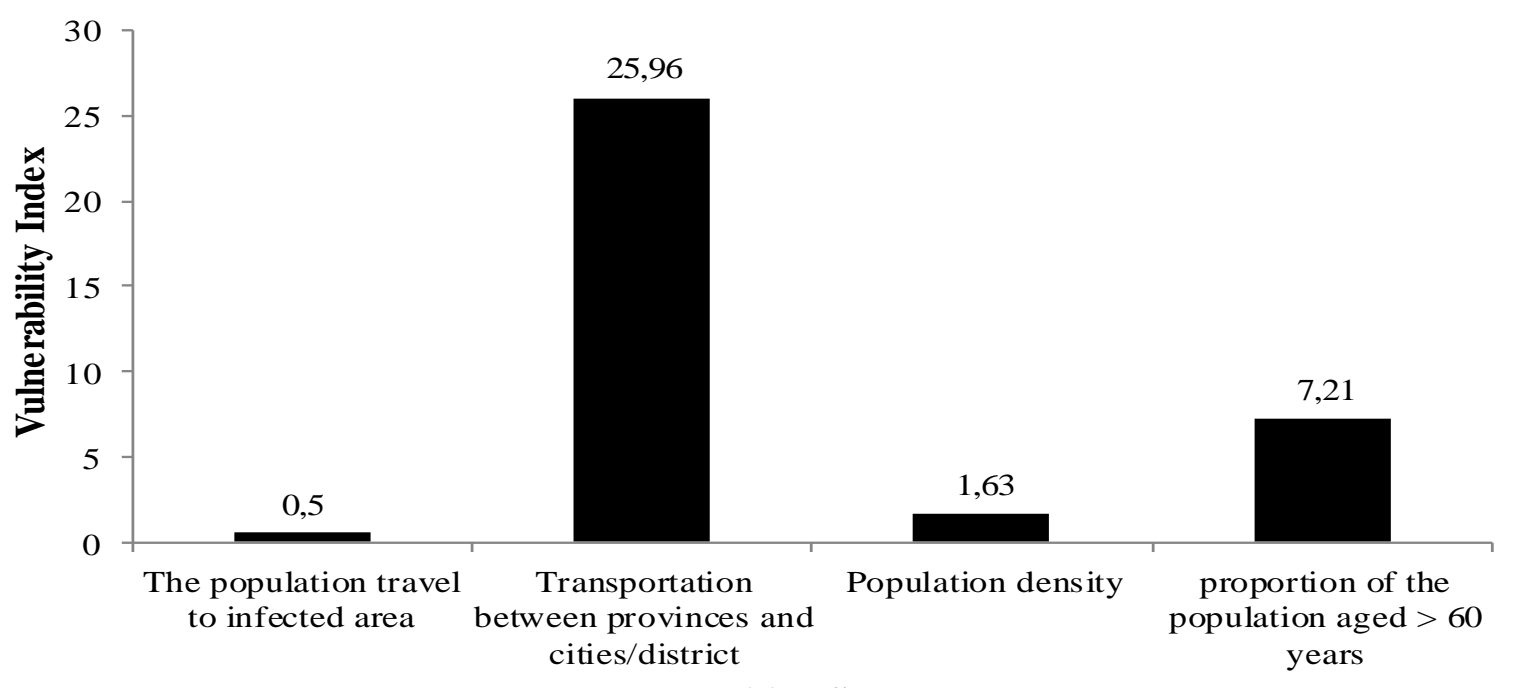

Vulne rability Subcategory

Figure 2. Results of Vulnerability Index from Formal Risk Assessment MERS-CoV

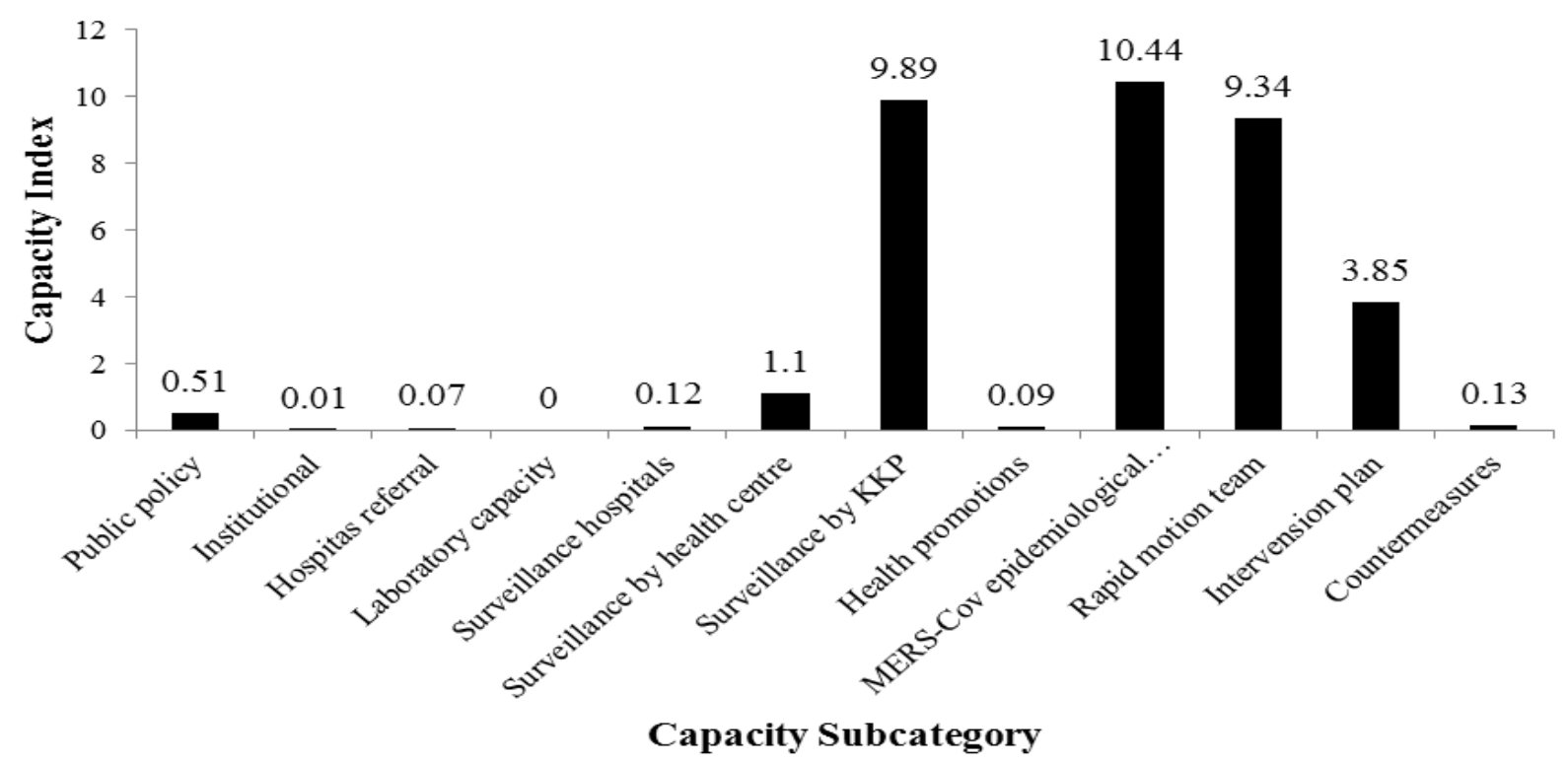

Figure 3. Results of Capacity Index of Formal Risk Assessment MERS-CoV

The Ministry of Health, as the highest government institution in the health sector in Indonesia, is attempting through PIE to maintain vigilance and response as well as capacity improvement in the effort to overcome emerging infectious diseases. The role of capacity improvement is very important in reducing the risk of MERS-CoV. Since 2018, the FRA tool has been used to conduct emerging infectious disease risk analysis, which includes analysis of threat risk, vulnerability, coping capacity, and emerging infectious diseases (Imari \& Lestari, 2017).

\section{Risk analysis of threat}

The risk assessment of the threat of MERS$\mathrm{CoV}$ disease showed high results for the disease characteristics subcategory, which was 30.25 . This is supported by a theory that explains that MERS$\mathrm{CoV}$ disease is one of the respiratory diseases that can cause symptoms ranging from fever, cough, shortness of breath, and other acute breathing. The virus of this disease is estimated to spread from the respiratory secretions of infected people to others through close contact (Nassar, Bakhrebah, Meo, Alsuabeyl, \& Zaher, 2018). As MERS-CoV can be transmitted from human to human through close contact, this makes the emergence of MERS-CoV 
disease a big threat. The Nassar et al. study is supported by Fehr, Channappanavar, \& Perlman (2016) who state that the prevalence of MERS$\mathrm{CoV}$ disease will increase substantially if the virus mutates to increase human-to-human transmission.

The results of the study, which also showed a high threat index value, were found in prevention subcategory index value of 23.56. Results in this subcategory indicated that prevention of MERS$\mathrm{CoV}$ disease is important. This is in line with other studies which state that prevention efforts against MERS-CoV need to be designed to contribute to increased preparedness that is more efficient in preventing future transmission of MERS-CoV (Kim et al., 2015). Other studies that are in line with the results of this study indicate that countries outside the region affected by MERS-CoV must maintain a high level of alertness and prevention, especially countries with large numbers of travellers or workers returning from the Middle East such as Indonesian workers (Bhatia, Sethi, Gupta, \& Biyani, 2016).

The risk of importation is also a subcategory of the threat factor to MERS-CoV disease, which gets a high threat index value of 11.25 (see Figure 1). Based on these results, it can be said that the risk of importing MERS-CoV disease is quite high in Indonesia. This risk has a huge impact on Indonesia, especially on the large number of Indonesian pilgrims who depart annually to Saudi Arabia. This was evident in the 2018 pilgrimage when 205,886 pilgrims departed Indonesia for the holy land of Mecca (Ministry of Religion RI, 2018). This condition allowed a high risk of close contact between fellow pilgrims from Indonesia, Saudi Arabia, and the world and has raised the possibility of the MERS-CoV virus spreading to Indonesian pilgrims and beyond (Rampengan, 2016).

\section{Risk analysis of susceptibility}

In this study, the subcategory of population travelling to the affected regions had a low susceptibility index value of 0.52 . Based on the guidelines of FRA conclusions, a low susceptibility index value indicates that there is no indication of a large impact of these subcategories on the possibility of MERS-CoV disease transmission. The results and conclusions of this study were different from the study conducted by Imari \& Lestari (2017), which stated that population travel to the affected country as a result of the development of mass transportation can increase the transmission of MERS-CoV disease between regions and countries more quickly, which has a big impact on the country and society.

The results of the low susceptibility index assessment in the subcategory of population travel to the affected regions were based on the results of evaluations by PIE subdirectorat staff. One of the reasons was because the questions in the FRA MERS-CoV questionnaire for this subcategory only asked for the number of pilgrims in a region that year and did not include data on the number of Umrah pilgrims. PIE subdirectorat staff will improve the questions in this subcategory by adding questions regarding the number of Umrah pilgrims in a region at a given time. The addition of data on the number of Umrah pilgrims in the risk assessment of MERS-CoV disease is considered important because, in Indonesia, the number of Umrah pilgrims, according to Kementerian Agama Republik Indonesia data, is three times greater than the number of pilgrims (Ministry of Religion RI, 2018).This large number of Umrah pilgrims increases the risk of transmitting MERS-CoV after they return to Indonesia (Lessler et al., 2014).

Another question that could improve this questionnaire is a question about the number of Indonesian workers working in the Middle East. This question needs to be added because of the high number of Indonesian workers departing for Saudi Arabia, which has reached more than one million Indonesian workers every year. The three groups (pilgrims, Umrah pilgrims, and migrant workers) have a risk of getting infected with MERS-CoV and can spread it in Indonesia.

In the transportation between provinces and cities/regencies subcategory, the high susceptibility index value obtained was 25.96. Based on this result, the high value of the transportation between provinces and cities/regencies subcategory cannot be interpreted directly as one of the susceptibility factors that caused the occurrence of MERS-CoV disease, which was increasingly high. This is because the transportation between provinces and cities/regencies does not have an epidemiological relationship to the cause of MERS-CoV disease. Epidemiological relationships are conditions that give a group or a population the possibility of being exposed to and infected by disease-causing agents (Gulis \& Fujino, 2015). The transportation between provinces and cities/regencies does not meet the criteria for causing a population exposed to MERS-CoV disease agents, because, based on the results of a study conducted by Gardner, Chughtai, \& Maclntyre (2016), a significant 
relationship to the spread of MERS-CoV is transportation between countries, especially transportation to MERS-CoV-affected countries like the Middle East. Another thing that causes this subcategory to not be a direct susceptibility factor for MERS-CoV disease is that the questions in the FRA questionnaire do not describe, and are insufficient to explore, MERS-CoV susceptibility information due to transportation between provinces and cities/regencies. So, to make this subcategory part of the MERS-CoV disease susceptibility index assessment, there need to be questions in the questionnaire that examine the transportation between provinces and cities/regencies.

Population density is also a susceptibility subcategory of MERS-CoV disease. The results in the population density subcategory obtained a low susceptibility index value of 1.63 . This showed that in the low population travel to affected regions subcategory, this subcategory did not have a high susceptibility to cause MERS-CoV disease. This was different from the study conducted by Fitria, Wahjudi, \& Wati (2014), which stated that significant population density affected the prevalence of MERS-CoV disease. The higher the density, the higher the sufferer's contact with healthy people, so more people will be exposed to the MERS-CoV virus.

The results of the susceptibility index assessment on proportion subcategory of the population aged $>60$ years showed a high index value of 7.21. The high calculation number for this subcategory is directly proportional to the calculation data by the Central Bureau of Statistics, which stated that the number of elderly people in Indonesia in 2018 was 24.49 million (9.27\%) and predicted that the elderly population in Indonesia would reach 63.31 million people or almost 20\% of the population by 2045 (Silviliyana et al., 2018).

The higher the index value for the subcategory of the proportion aged $>60$ years in the FRA assessment, the greater the susceptibility of a country to the spread of MERS-CoV disease. This is a result of the high number of elderly people in the population. This study was in line with the findings of other studies that stated that people at high risk of being infected with MERS$\mathrm{CoV}$ are children and people over 50 years of age with co-morbids such as diabetes, chronic heart disease, chronic lung disease, kidney disorders, immunity problems (such as malnutrition and AIDS), as well as workers or visitors to health and farm facilities (Arabi et al., 2017).
One aspect of life related to the transmission of MERS-CoV disease among the elderly is the organisation of Hajj and Umrah pilgrimages. This aspect is reflected in the condition that candidate pilgrims in Indonesia are dominated by elderly pilgrims (over 65 years). This condition is caused by the long waiting period to get a turn at making a pilgrimage to Mecca. The long waiting period is positively correlated with the increase in the age of candidate pilgrims in Indonesia. A waiting period could be as long as 42 years, which means that if a candidate pilgrim registers at the age of 35 years, he or she will be 77 at the time of departure. At that age, the physical health conditions of the pilgrim will have weakened, putting the pilgrim at a greater risk of disease. Diseases suffered by the elderly during a pilgrimage need to be watched out for, as they may be susceptible to MERS-CoV disease because they are in Saudi Arabia, the country with the highest incidence of MERS-CoV in the world (Widyarini, 2016).

\section{Risk analysis of capacity}

In the institutional subcategory in this study, the value of the low capacity index was obtained. This showed that the institutional role was still not maximal in conducting risk assessments of MERS$\mathrm{CoV}$ disease. The results of this study were in line with the results of evaluations carried out by the PIE staff - namely, there were still weaknesses in human resources (HR) in carrying out FRA. The weakness of HR that occurred was undisciplined regional officers filling out the FRA questionnaire form and non-compliance of officers in giving feedback to PIE on the questionnaire that had been filled out. Based on this, it can be concluded that the institutional subcategory obtained a low value because the institutions that play a role in preventing MERS-CoV cannot be maximally assessed because of the limitations of the HR personnel who conduct the FRA questionnaire assessment. The institutional role in carrying out its duties and functions can be said to be maximal if each member of the institution can make a good contribution to achieve a common goal. This is in line with a study that found a positive relationship between organisational support and the readiness of leaders to use effective teamwork to improve organisational performance (Abuzid \& Abbas, 2017). Based on this statement, improving the low condition of the institutional subcategory can be done by finding competent HR personnel to examine and assess the FRA questionnaire so that the institution can be assessed maximally. 
The development of existing surveillance activities in Indonesia in the context of early detection of emerging infectious diseases is more to utilise existing surveillance activities, both indicator-based and event-based surveillance. Given that emerging infection is a disease that is unknown or not seen for some time, and its characteristics are often symptoms and signs of several diseases, then a syndrome-based surveillance system should be developed (NiiTrebi, 2017). Syndrome surveillance is an observation of a collection of symptoms that lead to a particular disease or group of diseases. This activity is carried out in hospitals with the aim of detecting the incidence of disease early from a clinical symptom approach, which is subsequently confirmed through laboratory examinations (Vasconcelos \& Frias, 2017).

Based on the results of the capacity index assessment, the hospital surveillance subcategory obtained a low index value. This is because in Indonesia, while the emerging infectious disease surveillance system with a new syndrome approach was piloted by PIE in October 2018 in two hospitals (namely the Infection Hospital of Prof. Dr Sulianti Saroso and the Friendship Centre General Hospital of East Jakarta), it has not been fully implemented in all hospitals in Indonesia. This has led to this approach not being concluded effectively as an effort to comprehensively prevent and handle MERS-CoV in Indonesia and has caused a low index value in this subcategory.

In the subcategory of health centre surveillance, a low capacity index value was obtained. This is in line with the findings that there is still low supervision and monitoring carried out by the Health Office and health centre on the HHAC (Hajj Health Awareness Card) for Hajj pilgrims and Health Alert Cards (HAC) for Umrah pilgrims on the return of Hajj and Umrah pilgrims at the airport and the Hajj debarkation dormitory. This finding is also in line with other studies which have found that many debarkation officers fail in fully completing the Hajj Pilgrimage Health Book (HPHB), making it difficult to identify pilgrims at high risk (Hoesea, 2014).

The results of the regional entrance surveillance subcategory capacity index assessment by the KKP obtained a high index value. This result proves that the role and position of the KKP as the spearhead of the health service surveillance system - especially at the entrance of the regions, which includes seaports, airports, and land borders - are in accordance with the duties and functions of KKP.
The regional entrance surveillance subcategory by the KKP was right if it obtained a high index value because the methods carried out in surveillance activities have been carried out according to the standard operating procedures set. This is in line with the results of a study that showed that epidemiological surveillance activities at KKP, on process up to output activities, have been running well, according to the indicators set by Kementerian Kesehatan Republik Indonesia (Al ghozali, 2016).

\section{CONCLUSION}

The conclusions from this study indicate that the implementation of risk assessments of MERSCoV with the FRA method in 2018 as a whole was maximally pursued, but the results were still lacking. The lack of FRA based on threat, susceptibility, and capacity factors was threefold: (a) it did not include questions on the number of Umrah pilgrims and the number of Indonesian migrant workers; (b) there was no epidemiological relationship between transportation between provinces and cities/regencies with MERS-CoV susceptibility, and (c) there was unsatisfactory assessment and filling out of the FRA questionnaire by HR personnel. These deficiencies still need to be corrected through further intervention. Follow-up interventions are used to reduce the subcategory value, which is high in the threat and susceptibility index, and to increase the value of the capacity index, which is still low. Some follow-up interventions that can be done are in the form of an in-depth study of the content of the FRA questionnaire, so that collaboration between questionnaire and assessment subcategories can occur (especially in the transportation subcategory questionnaire). Improvement suggestions for the implementation of the FRA are the establishment of competent HR personnel to fill out the FRA questionnaire, and hospital-based syndrome surveillance conducted evenly all over hospitals in Indonesia.

\section{ACKNOWLEDGEMENT}

The author expresses gratitude to Menteri Kesehatan Republik Indonesia, Direktur Jenderal Pencegahan dan Pengendalian Penyakit Kementerian Kesehatan, Direktur Surveilans dan Karantina Kesehatan, dan Kepala Subdirektorat Penyakit Infeksi Emerging and staff for their contributions to this research. 


\section{REFERENCES}

Abuzid, H. F. T., \& Abbas, M. (2017). Impact of teamwork effectiveness on organizational performance vis-a-vis role of organizational support and team leader's readiness: a study of Saudi Arabian Government Departements work teams. Journal of Engineering and Applied Sciences, 12(8), 2229-2237.

Al ghozali, J. A. (2016). Evaluation of epidemiological surveillance activities at ports in efforts to prevent avian influenza outbreaks. The Indonesian Journal of Public Health, 11(1), 99. https://doi.org/10.20473/ijph.v11i1.2016.99109

Arabi, Y. M., Balkhy, H. H., Hayden, F. G., Bouchama, A., Luke, T., Baillie, J. K., ... Fowler, R. A. (2017). Middle east respiratory syndrome. New England Journal of Medicine, 376(6), 584-594. https://doi.org/10.1056/NEJMsr1408795

Bhatia, P. K., Sethi, P., Gupta, N., \& Biyani, G. (2016). Middle East respiratory syndrome: a new global threat. Indian Journal of Anaesthesia, $\quad 60(2), \quad 85-88$. https://doi.org/10.4103/0019-5049.176286

Fehr, A. R., Channappanavar, R., \& Perlman, S. (2016). Middle East respiratory syndrome: emergence of a pathogenic human coronavirus. Annual Review of Medicine, 68(1), 387-399. https://doi.org/10.1146/annurev-med051215-031152

Fitria, L., Wahjudi, P., \& Wati, D. M. (2014). Mapping the level of regional vulnerability to infectious diseases (pulmonary TB, DHF, and diarrhea) in Lumajang Regency in 2012. E-Journal Pustaka Kesehatan, 2(3), 460467.

Gardner, L. M., Chughtai, A. A., \& Maclntyre, C. R. (2016). Risk of global spread of Middle East respiratory syndrome coronavirus (MERS-CoV) via the air transport network. Journal of Travel Medicine, 23(6), 1-8. https://doi.org/10.1093/jtm/taw063

Gulis, G., \& Fujino, Y. (2015). Epidemiology, population health, and health impact assessment. Journal of Epidemiology, 25(3), 179-180. https://doi.org/10.2188/jea.je20140212

Hoesea, E. V. (2014). Evaluation of 2013 hajj health surveillance activities at the Hajj Embarkation "Antara" Palangkaraya. Jurnal Berkala Epidemiologi, 2(2), 206-215.
Imari, S., \& Lestari, A. D. P. (2017). Standard mapping of emerging infectious disease risks. Jakarta: Ministry of Health RI.

Ki, M. (2015). 2015 MERS outbreak in Korea: hospital-to-hospital transmission. Epidemiology and Health, 37(e2015033), 14. https://doi.org/10.4178/epih/e2015033

Kim, J. Y., Song, J. Y., Yoon, Y. K., Choi, S.-H., Song, Y. G., Kim, S.-R., ... Cheong, H. J. (2015). Middle east respiratory syndrome infection control and prevention guideline for healthcare facilities. Infection and Chemotherapy, 47(4), 278-302. https://doi.org/http://dx.doi.org/10.3947/ic.20 15.47.4.278

Lessler, J., Rodriguez-Barraquer, I., Cummings, D. A. T., Garske, T., Van Kerkhove, M., Mills, H., ... Ferguson, N. M. (2014). Estimating potential incidence of MERS-CoV associated with hajj pilgrims to Saudi Arabia, 2014. PLoS Currents Outbreaks, 1-17. https://doi.org/10.1371/currents.outbreaks.c5 c9c9abd636164a9b6fd4dbda974369

Monge-Maillo, B., \& López-Vélez, R. (2017). Challenges in the management of Chagas disease in Latin-American migrants in Europe. Clinical Microbiology and Infection, 23(5), 290-295. https://doi.org/10.1016/j.cmi.2017.04.013

Ministry of Religion RI. (2018). Infografis haji Indonesia tahun 1949-2018. Ministry of Religion RI. Jakarta.

Mukherjee, S. (2017). Emerging infectious diseases: epidemiological perspective. Indian Journal of Dermatology, 62(5), 459-467. https://doi.org/10.4103/ijd.IJD_379_17

Nassar, M. S., Bakhrebah, M. A., Meo, S. A., Alsuabeyl, M. S., \& Zaher, W. A. (2018). Middle East respiratory syndrome coronavirus (MERS-CoV) infection: epidemiology, pathogenesis and clinical characteristics. European Review for Medical and Pharmacological Sciences, 22(15), 4956-4961. https://doi.org/10.26355/eurrev_201808_156 35

Nii-Trebi, N. I. (2017). Emerging and neglected infectious diseases: insights, advances, and challenges. BioMed Research International, 1-15. https://doi.org/10.1155/2017/5245021

Rampengan, N. H. (2016). Middle East respiratory syndrome coronavirus. Jurnal Biomedik (JBM), 8(1), 17-26. https://doi.org/10.1177/2165079915607497

Silviliyana, M., Maylasari, I., Agustina, R., 
Ramadani, K. D., Sulistyowati, R., Annisa, L., \& Dewi, F. W. R. (2018). Elderly population statistics (Susilo, D., Harahap, I.E., \& Sinang, R, Eds.). Jakarta: Central Bureau of Statistics.

Vasconcelos, C. S. de, \& Frias, P. G. de. (2017). Evaluation of the influenza-like syndrome surveillance: case studies in sentinel unit. Saúde Em Debate, 41(especial), 259-274. https://doi.org/10.1590/0103-11042017s19

WHO. (2019). Epidemic and pandemic-prone disease: MERS situation update, February 2019. World Health Organization. Geneva. Retrieved March, 26, 2019, from http://applications.emro.who.int/docs/EMRO Pub_2019_MERA_May_EN_23546.pdf?ua= $1 \& u a=1$

Widyarini. (2016). Hajj implementation for the elderly. Az Zarqa, 8(2), 219-235. 